\title{
A tribute to Antonin Rychtecky - his European legacy in youth sport and Olympic education studies
}

\author{
Roland Naul
}

\author{
Willibald Gebhardt Institute, Münster, Germany \\ r.naul@wwu.de \\ DOI
}

$10.14712 / 23366052.2021 .1$

My first meeting with Antonin Rychtecky is dated back to October 3rd in 1988, some months before the Velvet Revolution in Czechoslovakia. It was my colleague HansGeorg John who invited me to join him on his Prague trip to be introduced to his friend Miroslav Pliva and to be introduced to a new colleague who worked in the same area of my academic work: Antonin Rychtecky. This 1988 October trip was well prepared: I was invited by Antonin Rychtecky to present a paper on how sport pedagogy as a discipline may offer support and advice to elite athletes. The presentation was given at the old faculty facilities, downtown by the river Vltava, just beside the Tyrs Museum. I was invited to join a group of faculty scientists who investigated Prague school children of regular schools and special sport schools to compare their physical fitness and motor development profiles. In the 1980s empirical studies in PE with physical fitness test batteries were not common and almost unknown in West Germany. We recorded by video tape everything we saw, in which way the test items were conducted by children and how measurements were taken by the Prague faculty team.

We took the video tapes back to Essen, where I had been working since 1980 . We trained our team of colleagues and students to apply the same test battery to children of the same age group, in regular Essen school classes, according to the protocol applied to the Prague children by the Prague faculty team in doing their measurements. The outcome was the first co-authored three year longitudinal comparative study of West German and Czech school children regarding their motor and physical fitness profiles. The fresh results were reported at the International Comparative PE and Sport conference in Bishop Abbey, London, 1990, and published later, co-authored 
by Antonin Rychtecky, Miroslav Pauer and Roland Naul (1991). That was our first co-authored international publication. Only a year later, in 1992, the overall results of our Prague-Essen monitoring project on physical fitness and motor development were presented at the ICSSPE Pre-Olympic Scientific Congress in the city of Malaga, published later in Spanish (Naul, Neuhaus, \& Rychtecky, 1995). As a research co-ordinator of the International Society of Comparative Physical Education and Sport (ISCPES) I supported the bid of the Faculty of Physical Education and Sport (FTVS) submitted by Bohumil Svoboda and Antonin Rychtecky to host the next ISCPES Congress in Prague, in 1994. The outcome of the congress was very successful, as reflected in the proceedings of the Congress documents (Svoboda \& Rychtecky, 1995).

The Olympic Year of 1994 became the real turning point for Antonin to join a greater European research project which included the monitoring of Olympic ideals for the first time in 12 and 15 year-old adolescents. It was a European six-country project (BEL, CZE, EST, FIN, GER, HUN) launched by the International Committee of Sport Pedagogy (ICSP) with a grant from the IOC. It was a study of around 7,000 students to investigate coherent development between physical fitness, active lifestyle behaviour and the assessment of moral principles as Olympic ideals. Some of the earliest comparative results were published in Acta Universitatis Carolinae - Kinanthropologica (Naul, Telama, \& Rychtecky, 1997) and the full range of results were published in a book, volume 11 of the "Sport Science Studies" series of ICSSPE (Telama et al., 2002).

One international highlight performed by Antonin Rychtecky in his Olympic education studies was the result of a so-called "four Olympic ideal factors as behaviour patterns" project (Rychtecky \& Naul, 2005) which became well referenced later in international publications, just like the "Olympic Questionnaire" of the ICSP-study which was developed in cooperation with him. The "Olympic Questionnaire” was later applied worldwide in Hong Kong, Singapore, USA, South Africa and even more frequently in some European countries, particularly in Poland and Ukraine. The structure and frame of the ICSP study design were also taken later by Prof. Rychtecky himself $(2011,2013,2021)$ for two more national cohort studies on physical activity and Olympic ideals of adolescents in the Czech Republic.

A second big European project with FTVS and Antonin Rychtecky as an important partner network emerged in 2003, when a European research consortium of scholars, representing $11 \mathrm{EU}$ member states was selected by the European Commission to conduct an EU-wide study on young peoples' physical activities and sedentary lifestyles (Naul \& Brettschneider, 2005). The considerable income generated by the German lead partner was fairly distributed and shared between all partners of the review study in which Antonin Rychtecky represented the Czech partner. In total, we received more than a dozen national review studies including many national research results which had previously only been published in very different national EU languages like Czech, Portuguese, Finnish, etc. In this project, these different national sources, which had up until then remained largely unknown to an international audience because of language barriers, were brought to an international level of recognition and knowledge in Europe. A major contribution was made by Prof. Rychtecky. He not only wrote his report for the Czech Republic, but also became our mentor and translator to get in contact with scientists in Poland, Slovakia and Slovenia for their national reports 
in English. Finally, Antonin summarized the outcome of the four national country reports on physical activity development and physical fitness from Central \& Eastern Europe in a special volume (Rychtecky, 2004).

The final report of this study, stored at the European Commission library, caused some further activities after 2005: the first European Union Working Group on Sport and Health was established in Brussels (2006). Only eight EU countries sent their national delegates. Antonin Rychtecky represented the Czech Republic in this group. This group had a remit to draft the EU-Physical Activity Guidelines and brought up HEPA again on the EC agenda after 1999/2000. In the mid of the 2000s Antonin was also an invited and elected member of some other EC projects: he was a member of numerous research consortia linked to commissioned studies for the European Union (e.g. COMPASS Study; Study on Young People's Lifestyle and Sedentariness; VOCAsport; ARCTOS; AEHSIS).

As a part of the so called "Preparatory actions in the field of sport", another EU-project grant was awarded in 2009 up to 2011 by DG EAC (the Commission department in charge of sport, inter alia) and managed by us on behalf of ENGSO Youth and the German Sport, Youth with support of the Prague Faculty as a partner. A strong Czech sample of secondary school children of the city of Prague and two more schools in the town of Vrchlabí were included in cooperation with CSTV. Antonin Rychtecky served as the head of the Czech national HCSC-study (healthy children in sound communities) which results are documented in the final report of the EC-project.

Finally, another big world-wide project was launched about 10 years ago, but only came to life in 2012, and has been finished only in 2017. It is a 20-country study around the world with 9 EU-partners representing countries like Czech Republic, France, Germany, Greece, Poland, Russia, Spain, UK and Ukraine (Naul, Binder, Rychtecky \& Culpan, 2017). With a comparative set of about 15 items of review criteria in total 20 national country reports have been written with additional 8 chapters of introduction and international analysis of the reported review results. Besides the Czech national country report, written by Antonin, four chapters of the anthology have been written together in international co-authorship with Prof. Rychtecky.

In the same year of 2017 Antonin, "Tonda", helped us as our international fellow of the Willibald Gebhardt Research Institute at Münster, to celebrate the 4th Olympic Education Symposium at the Charles University. We intended to dedicate the proceedings of the symposium to Anton Rychtecky's 75 birthday in September 2020. However, before printing of the final manuscript started, Prof. Rychtecky passed away. We just dedicated the book as a tribute to the life-work of Antonin Rychtecky (Binder et al., 2021) with inclusion of a review paper of Prof. Rychtecky which he gave at the symposium in Prague. It will be printed as a part of the proceedings posthumously (Rychtecky, 2021).

Without the support of my friend Tonda at the faculty in Prague, we never would have had access to sources and materials written by our Russian and Ukrainian Olympic scholars in this world-wide project. In many research projects Prof. Rychtecky with his perfect Russian academic language skills opened doors to Eastern Europe with involvement of Slavonian language countries. As a teacher he lectured as a member of the Czech National Olympic Academy frequently on Olympic education items at the International Olympic Academy in Ancient Olympia. 
With the passing of Prof. Rychtecky, the FTVS lost one of their most prominent academic representatives in Europe and within the Olympic family world-wide. The Willibald Gebhardt Research Institute will keep our memories of Tonda as a friend and international fellow alive after more than 30 years of academic cooperation.

\section{REFERENCES}

Binder, D., Naul, R., \& Fialova, L. (Eds.) (2020). Olympic education - history, theory, practice. Proceedings of the 4th Willibald Gebhardt Olympic Symposium. Aachen: Meyer \& Meyer.

Naul, R., Binder, D., Rychtecky, A., \& Culpan, I. (Eds.) (2017). Olympic education. An international review. London/New York: Routledge.

Naul, R. \& Brettschneider, W. D. (2005). Young people's lifestyles and sedentariness in Europe. Acta Universitatis Carolinae Kinanthropologica, 41(2), 25-34.

Naul, R., Neuhaus, W., \& Rychtecky, A. (1995). La Importancia de las Actividades Fisicas Diaturaciones Motrices Especiales: Un Estudio Piloto Inter-Cultural y Longitudinal. In: M. Noguera (Ed.), Actas Congreso Cientifico Olympico 1992. Pedagogica y Edaucation Fisica Comparada Vol. III (pp. 189-198). Malaga: Instituto Andaluz del Deporte.

Naul, R., Pauer, M., \& Rychtecky, A. (1991). Daily Physical Activities and Motor Performance of West German and Czechoslovakian School Children. In: J. Standeven, K. Hardman $\&$ D. Fisher (Eds.), Sport for all. Into the 90s; comparative physical education and sport. Seventh International Society on Comparative Physical Education and Sport Conference (pp. 204-211). Aachen: Meyer \& Meyer.

Naul, R., Telama, R., \& Rychtecky, A. (1997). Physical Fitness and Active Lifestyle of Czech, Finnish and German Youth. Acta Universitatis Carolinae Kinanthropologica, 33(2), 5-15.

Rychtecky, A. (2004). Study on young people's lifestyles and sedentariness and the role of sport in the context of education and as a means of restoring the balance. Czech, Polish, Slovak, and Slovenian cases. Prague: UK FTVS.

Rychtecky, A. (2013). Are Olympians real idols of young people for their motivation and participation in sport? Acta Universitatis Carolinae Kinanthropologica, 49(1), 65-76.

Rychtecky, A. (2021). Teaching Olympic education and education through sport in the Czech Republic. In: D. Binder, R. Naul, \& L. Fialova (Eds.), Olympic education - history, theory, practice. Proceedings of the 4th Willibald Gebhardt Olympic Symposium (pp. 91-105). Aachen: Meyer \& Meyer.

Rychtecky, A., Dovalil, J., Tilinger, P., \& Kricek, J. (2011). Participation in sport, knowledge of Olympic facts and assessment of Olympic values in Czech young people. Acta Universitatis Carolinae Kinanthropologica, 47(1), 96-106.

Rychtecky, A. \& Naul, R. (2005). Goal Orientation and Perception of Olympic Ideals in Czech and German Youth. Acta Universitatis Carolinae Kinanthropologica, 41(2), 35-48.

Svoboda, B. \& Rychtecky, A. (Eds.) (1995). Physical Activity for Life: East and West, South and North. Proceedings of the Ninth International Society on Comparative Physical Education and Sport Conference. Prague (pp. 22-25). Aachen: Meyer \& Meyer.

Telama, R., Naul, R., Nupponen, H., Rychtecky, A., \& Vuolle, P. (2002). Physical Fitness, Sporting Lifestyles and Olympic Ideals: Cross-cultural Studies on Youth Sport in Europe. Schorndorf: Verlag Karl Hofmann (vol. 11 of ICSSPE Sport Science Studies). 